\title{
Synthesis and Crystal Structure of $\mathrm{TI}_{0.8} \mathrm{Sn}_{0.6} \mathrm{Mo}_{7} \mathrm{O}_{11} \cdot \mathrm{Mo}_{14} \mathrm{O}_{34}$ Clusters Containing Three Condensed $\mathrm{Mo}_{6}$ Octahedra
}

\author{
Richard Dronskowski and Arndt Simon* \\ Max-Planck-Institut für Festkörperforschung, Heisenbergstrasse 1, D-7000 Stuttgart 80, Federal Republic of Germany
}

\begin{abstract}
Dronskowski, R. and Simon, A.. 1991. Synthesis and Crystal Structure of $\mathrm{Tl}_{0.8} \mathrm{Sn}_{0.6} \mathrm{Mo}_{7} \mathrm{O}_{11} . \mathrm{Mo}_{14} \mathrm{O}_{34}$ Clusters Containing Three Condensed $\mathrm{Mo}_{6}$ Octahedra. Acta Chem. Scand. 45 : 850-855.

The crystal structure of the new compound $\mathrm{Tl}_{10.8} \mathrm{Sn}_{0.6} \mathrm{Mo}_{7} \mathrm{O}_{11}\left[P 2_{1} / a, a=997.2(1)\right.$, $\left.b=936.2(1), c=1036.2(1) \mathrm{pm}, \beta=104: 14(1)^{\circ}, Z=4\right]$ contains oligomeric Mo clusters built up from three edge-sharing Mo octahedra in a row. The connectivity scheme of the clusters corresponds to $\mathrm{Mo}_{14} \mathrm{O}_{10} \mathrm{O}_{4 / 2}^{\mathrm{i}-\mathrm{i}} \mathrm{O}_{20 / 2}^{\mathrm{i}-\mathrm{a}}$. There are pairs of divalent $\mathrm{Tl}$ atoms linked by a single bond $(284 \mathrm{pm})$ in the channels of the structure as well as isolated divalent $\mathrm{Sn}$ atoms. The average Mo-O and Mo-Mo distances within the clusters lie around 206 and $278 \mathrm{pm}$ and are very similar to those in $\operatorname{In}_{11} \mathrm{Mo}_{40} \mathrm{O}_{62}$, but there also are short inter-cluster distances $\left(d_{\text {inter }} \geq 299 \mathrm{pm}\right)$. The Mo valence electron concentration derived from bond-length-bond-strength calculations is in perfect agreement with the expected value.
\end{abstract}

Dedicated to Professor Sten Andersson on the occasion of his 60th birthday.

Since the discovery of the compound $\mathrm{NaMo}_{4} \mathrm{O}_{6}{ }^{1}$ there have been extensive studies in the field of condensed clusters in oxomolybdates. $\mathrm{NaMo}_{4} \mathrm{O}_{6}$ contains infinite chains built from trans-edge-sharing $\mathrm{Mo}_{6}$ octahedra which are surrounded by $\mathrm{O}$ atoms as in the case of the $\mathrm{M}_{6} \mathrm{X}_{12}$ cluster. $^{2}$ Electronic band structure calculations ${ }^{3}$ (EHT-type) proved these chains to be optimally stabilized with 13 electrons per $\mathrm{Mo}_{4}$ fragment.

In addition to the large number of compounds that only contain infinite Mo chains (see $\mathrm{McCarley}^{4}$ and Simon ${ }^{5}$ ) there are also a few examples of "intermediates" of cluster condensation. ${ }^{6} \mathrm{In}_{11} \mathrm{Mo}_{40} \mathrm{O}_{62}$ was the first compound identified with finite chains of four and five edge-sharing $\mathrm{Mo}_{6}$ octahedra in a row, ${ }^{7}$ therefore containing oligomers of cluster condensation. Between the alternately packed oligomeric Mo units hitherto unknown metal-metal bonded In chains were found.

From an appropriate fragmentation of an oligomer into $\mathrm{Mo}_{4} \mathrm{O}_{7}, \mathrm{Mo}_{4} \mathrm{O}_{6}$ and $\mathrm{Mo}_{2} \mathrm{O}_{5}$ units one could estimate the optimum valence electron concentrations for clusters of arbitrary length ${ }^{5}$ in order to facilitate the synthesis of other "oligomeric" oxomolybdates. In addition to $\operatorname{In}_{11} \mathrm{Mo}_{40} \mathrm{O}_{62}$, compounds are known with one $\left(\mathrm{BaMo}_{6} \mathrm{O}_{10},{ }^{8}\right.$ single octahedron), two $\left(\mathrm{LaMo}_{5} \mathrm{O}_{8},{ }^{9} \quad \mathrm{PbMo}_{5} \mathrm{O}_{8}\right)^{10,11}$ and three $\left(\mathrm{Tl}_{0.8} \mathrm{Sn}_{0.6} \mathrm{Mo}_{7} \mathrm{O}_{11}\right)^{10}$ condensed Mo octahedra. Here we report in detail our investigations (synthesis and single-crystal structure analysis) of the latter compound.

* To whom correspondence should be addressed.

\section{Preparation}

Preparations in the system $\mathrm{Tl} / \mathrm{Sn} / \mathrm{Mo} / \mathrm{O}$ (molar composition $\approx 1: 1: 10: 14, T \approx 1570 \mathrm{~K}$ ) lead to hitherto unknown, black shiny crystals with a complicated Guinier diagram. They were brittle and "smeared" upon crushing. Fig. 1 shows a SEM photograph of a typical specimen. All crystals consisted of domains that were intergrown in three orientations differing by $120^{\circ}$ (similar to $\operatorname{In}_{11} \mathrm{Mo}_{40} \mathrm{O}_{62}{ }^{7}$ and $\left.\mathrm{PbMo}_{5} \mathrm{O}_{8}\right),{ }^{11}$ and the $(010)$ faces always had a characteristic "maple leaf" shape.

The chemical analysis of selected crystals $(7 \mathrm{mg})$ with AES/ICP yielded a ratio of $\mathrm{Tl}: \mathrm{Sn}: \mathrm{Mo} \approx 0.9: 0.7: 7$. The

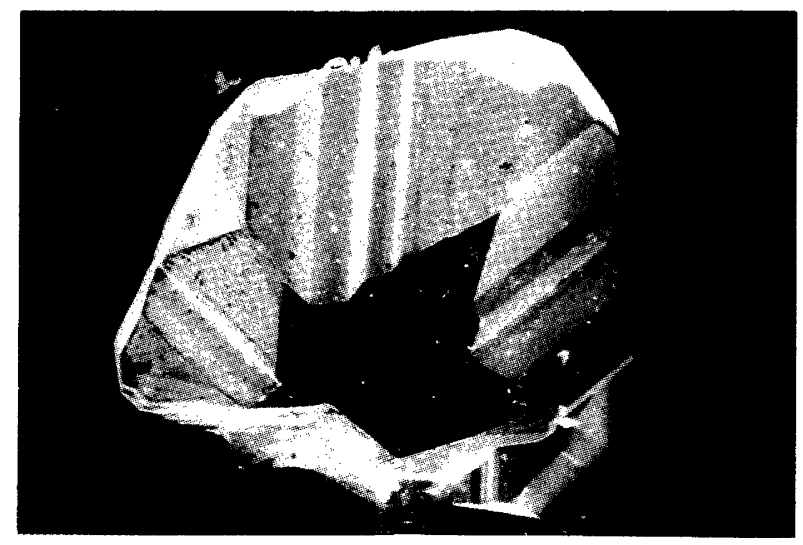

Fig. 1. SEM photograph of a "crystal" of $\mathrm{Tl}_{0.8} \mathrm{Sn}_{0.6} \mathrm{Mo}_{7} \mathrm{O}_{11}$. 
single-crystal refinement of individual site occupation factors led to the composition $\mathrm{Tl}_{0.8} \mathrm{Sn}_{0.6} \mathrm{Mo}_{7} \mathrm{O}_{11}$. Crystals up to $1 \mathrm{~mm}$ in size could be synthesized in a quantitative yield when choosing the latter metal atom ratio.

Synthesis. $1.535 \mathrm{~g} \mathrm{MoO}_{2}(12.0 \mathrm{mmol})$ (Ventron), $0.314 \mathrm{~g}$ Mo (3.3 mmol) (LAB, Merck), $0.357 \mathrm{~g} \mathrm{Tl}(1.7 \mathrm{mmol})$ (LAB, Merck) and $0.155 \mathrm{~g} \mathrm{Sn}(1.3 \mathrm{mmol})$ (p.a., Merck) were mixed and pressed to a pellet. The pellet was heated in an evacuated quartz glass ampoule for $7 \mathrm{~d}$ at $1573 \mathrm{~K}$. The ampoule was quenched with air (and recrystallized in about $5 \mathrm{~min}$ ). The product was single-phase.

\section{Structural analysis}

Any specimens as large as the one in Fig. 1 were of multiple domain and were therefore crushed under paraffin. Axes photographs of very small fragments proved them to be single-crystalline, showing sharp reflections which suggested an orthorhombic system from metrics but a monoclinic system from intensities.

The extinction rules $h 0 l, h=2 n$ and $0 k 0, k=2 n$ indicated space group $P 2_{1} / a\left(C_{2 h}^{5}\right.$, No. 14). For ease of comparison with the structures of $\mathrm{NaMo}_{4} \mathrm{O}_{6}, \mathrm{In}_{11} \mathrm{Mo}_{40} \mathrm{O}_{62}$ and $\mathrm{PbMo}_{5} \mathrm{O}_{8}$ the non-conventional setting was kept. Most of the heavy atom positions were found using direct methods, the rest being added from Fourier syntheses. ${ }^{12}$ The localization of some of the $\mathrm{O}$ atoms with the help of difference Fourier maps turned out to be difficult, as did the definite assignment of the heavy-atom densities for $\mathrm{Tl}$ and Sn, owing to the fact that they are disordered.

The Fourier map phased with the Mo-O partial structure reveals electron densities at the inversion centre in (i) $1 / 2$, $1 / 2,0$ and near (ii) $0.5,0.5,0.6$. The elongated peak shapes can be modelled by split positions with atomic positions that are separated by about $40 \mathrm{pm}\left(\mathrm{i}_{\mathrm{a}}\right.$ from $\left.\mathrm{i}_{\mathrm{b}}\right)$ and $60 \mathrm{pm}\left(\mathrm{ii}_{\mathrm{a}}\right.$ from $\mathrm{ii}_{\mathrm{b}}$ ), respectively. From bond-length-bond-strength and ionic radii considerations it is obvious that $\mathrm{Tl}$ has to occupy (i) and $\left(\mathrm{ii}_{\mathrm{a}}\right)$, whereas $\mathrm{Sn}$ has to enter $\left(\mathrm{ii}_{\mathrm{b}}\right) \cdot{ }^{13}$ This assignment is the only one which avoids meaningless site occupation factors (i.e. $>1$ ) in the following refinements.

At first the site occupation factors of $\mathrm{Tl}$ and $\mathrm{Sn}$ were refined, together with a common free-to-refine displacement factor, and yielded a composition of $\mathrm{Tl}(1): \mathrm{Tl}(2): \mathrm{Sn}$ $=0.383(2): 0.391(3): 0.603(5)$, with $U_{\text {eq }}=204 \mathrm{pm}^{2}$. This composition remained constant (within a single standard deviation) in refinements with independent anisotropic displacement parameters. The refined stoichoimetry of $\mathrm{Tl}_{0.8} \mathrm{Sn}_{0.6} \mathrm{Mo}_{7} \mathrm{O}_{11}$ therefore seems reliable.

The two-fold disorder of what looks like a structural unit, $\mathrm{Tl}-\mathrm{Tl}-\mathrm{Sn}$, in an otherwise centrosymmetric structure raises a question as to the nature of this disorder. It could be a statistic disorder or the result of meroedric twinning (inversion twins). Refinements in the acentric subgroups $P 2_{1}$ and $P a$ using the twin program SLFS ${ }^{14}$ gave a clear answer in favour of the first interpretation. Whereas the conventional refinement of the disorder model yielded $R_{\text {iso }} \approx 0.13$,
Table 1. Crystallographic data for $\mathrm{Tl}_{0.8} \mathrm{Sn}_{0.6} \mathrm{Mo}_{7} \mathrm{O}_{11}$.

\begin{tabular}{|c|c|}
\hline $\begin{array}{l}\text { Formula: } \\
\text { Molar mass } / \mathrm{g} \mathrm{mol}^{-1}\end{array}$ & $\begin{array}{l}\mathrm{Tl}_{0.8} \mathrm{Sn}_{0.6} \mathrm{Mo}_{7} \mathrm{O}_{11} \\
1082.31\end{array}$ \\
\hline \multicolumn{2}{|l|}{ Lattice constants } \\
\hline$a / p m$ & $997.2(1)$ \\
\hline$b / p m$ & $936.2(1)$ \\
\hline $\mathrm{c} / \mathrm{pm}$ & $1036.2(1)$ \\
\hline \multirow[t]{2}{*}{$\beta /{ }^{\circ}$} & $104.14(1)$ \\
\hline & $\begin{array}{l}\text { (modified Guinier technique, }{ }^{20} \\
21 \text { reflections) }\end{array}$ \\
\hline Molar volume $/ \mathrm{cm}^{3} \mathrm{~mol}^{-1}$ & $141.25(3)$ \\
\hline Space group & $P 2, / a, C_{2 h}^{5}$ (No. 14) \\
\hline Formula units & 4 \\
\hline X-ray density $/ \mathrm{g} \mathrm{cm}^{-3}$ & 7.662 \\
\hline Absorption coefficient $/ \mathrm{mm}^{-1}$ & 22.97 \\
\hline Crystal dimensions $/ \mathrm{mm}^{3}$ & $0.083 \times 0.071 \times 0.048$ \\
\hline Instrument & $\begin{array}{l}\text { Syntex } P \overline{1} \text { four-circle } \\
\text { diffractometer, Mo-K } K \alpha \text { radiation, } \\
\text { graphite monochromator, } \\
\text { scintillation counter }\end{array}$ \\
\hline Scan range $/^{\circ}$ & $3<2 \theta<50$ \\
\hline Scan type & Wyckoff scan \\
\hline Scan speed $/{ }^{\circ} \mathrm{min}^{-1}$ & $\begin{array}{l}\text { variable (1.5-19.5), dependent on } \\
\text { prescan }\end{array}$ \\
\hline Temperature / K & 296 \\
\hline No. of reflections & $\begin{array}{l}1882 ; 1438 \text { symmetry- } \\
\text { independent with } F_{0} \geq 3 \sigma\left(F_{0}\right)\end{array}$ \\
\hline Octants & $\begin{array}{l}-11 \leq h \leq 11,0 \leq k \leq 11 \\
0 \leq I \leq 12\end{array}$ \\
\hline Absorption correction & $\begin{array}{l}\psi \text { scan with } 11 \text { reflections, } \\
\text { pseudo-ellipsoid }\end{array}$ \\
\hline $\begin{array}{l}\text { Minimum, maximum } \\
\text { transmission }\end{array}$ & $0.10,0.18$ \\
\hline $\begin{array}{l}R_{\text {average }} \\
\text { Structure solution }\end{array}$ & $\begin{array}{l}0.036 \\
\text { direct methods (SHELXS-86) }\end{array}$ \\
\hline Structure refinement & $\begin{array}{l}\text { Least-squares method } \\
\text { (SHELX-76, XLS), } 16,17 \text { full matrix }\end{array}$ \\
\hline No. of structure factors & 1436 \\
\hline No. of variables & 193 \\
\hline Weighting scheme & $w=1 / \sigma^{2}\left(F_{0}\right)$ \\
\hline Extinction correction & $x=0.00062$ \\
\hline$R_{\text {aniso }}, R_{\mathrm{w}}$ & $0.051,0.046$ \\
\hline
\end{tabular}

including all metal atoms, the corresponding twin refinement did not drop below $R_{\text {iso }} \approx 0.18$.

A final control of $F_{\mathrm{o}}-F_{\mathrm{c}}$ differences (DIFABS) ${ }^{15}$ did not reveal any remaining absorption errors. After allowing for secondary extinction corrections all atoms could be refined anisotropically. ${ }^{16,17}$ Table 1 shows all relevant data for the structural analysis, ${ }^{18}$ while Table 2 contains positional and isotropic displacement parameters. ${ }^{19}$ Table 3 lists the reflections from powder diffraction data ${ }^{20}$ used in the refinement of the lattice constants. ${ }^{21}$ From Table 4 all important interatomic distances ${ }^{22}$ can be obtained. ${ }^{23}$

\section{Description and discussion of the structure}

$\mathrm{Tl}_{0.8} \mathrm{Sn}_{0.6} \mathrm{Mo}_{7} \mathrm{O}_{11}$ is a member of the family composed of oligomeric Mo clusters. A projection of its structural principle is shown in Fig. 2. The cluster anions which are represented by their cores of three $\mathrm{Mo}_{6}$ octahedra con- 
Table 2. Positional parameters, site occupation factors (SOF) and isotropic displacement parameters $\left(\mathrm{pm}^{2}\right)$ for

$\mathrm{Tl}_{0.8} \mathrm{Sn}_{0.6} \mathrm{Mo}_{7} \mathrm{O}_{11}$ (standard deviations are given in parentheses).

\begin{tabular}{llllll}
\hline Atom & $x$ & $y$ & $z$ & SOF & $U_{\text {eq }}{ }^{a}$ \\
\hline $\mathrm{TI}(1)$ & $0.5132(2)$ & $0.5036(2)$ & $0.0182(2)$ & $0.39(1)$ & $274(7)$ \\
$\mathrm{TI}(2)$ & $0.5612(3)$ & $0.4934(3)$ & $0.2998(3)$ & $0.38(1)$ & $212(9)$ \\
$\mathrm{Sn}$ & $0.4550(3)$ & $0.5006(3)$ & $0.6488(4)$ & $0.61(1)$ & $229(9)$ \\
$\mathrm{Mo}(1)$ & $0.1191(1)$ & $0.3855(1)$ & $0.1391(1)$ & 1 & $113(4)$ \\
$\mathrm{Mo}(2)$ & $0.9131(1)$ & $0.3809(1)$ & $0.2819(1)$ & 1 & $141(4)$ \\
$\mathrm{Mo}(3)$ & $0.2261(1)$ & $0.6314(1)$ & $0.2833(1)$ & 1 & $155(4)$ \\
$\mathrm{Mo}(4)$ & $0.8440(1)$ & $0.3726(2)$ & $0.0010(2)$ & 1 & $176(5)$ \\
$\mathrm{Mo}(5)$ & $0.1920(1)$ & $0.3843(1)$ & $0.4127(1)$ & 1 & $112(4)$ \\
$\mathrm{Mo}(6)$ & $0.0503(1)$ & $0.3821(1)$ & $0.8636(1)$ & 1 & $122(4)$ \\
$\mathrm{Mo}(7)$ & $0.9751(1)$ & $0.3777(2)$ & $0.5841(1)$ & 1 & $169(5)$ \\
$\mathrm{O}(1)$ & $0.3261(11)$ & $0.7576(11)$ & $0.9984(11)$ & 1 & $209(40)$ \\
$\mathrm{O}(2)$ & $0.3990(10)$ & $0.7561(11)$ & $0.2846(10)$ & 1 & $148(37)$ \\
$\mathrm{O}(3)$ & $0.3175(10)$ & $0.2537(10)$ & $0.5705(10)$ & 1 & $124(35)$ \\
$\mathrm{O}(4)$ & $0.1491(11)$ & $0.5008(11)$ & $0.5712(11)$ & 1 & $206(36)$ \\
$\mathrm{O}(5)$ & $0.2185(10)$ & $0.5056(11)$ & $0.8588(10)$ & 1 & $181(34)$ \\
$\mathrm{O}(6)$ & $0.7126(10)$ & $0.4897(12)$ & $0.8547(11)$ & 1 & $238(39)$ \\
$\mathrm{O}(7)$ & $0.3913(12)$ & $0.2587(12)$ & $0.8600(12)$ & 1 & $207(38)$ \\
$\mathrm{O}(8)$ & $0.6453(10)$ & $0.4920(11)$ & $0.5749(10)$ & 1 & $162(34)$ \\
$\mathrm{O}(9)$ & $0.9687(11)$ & $0.7432(10)$ & $0.5682(10)$ & 1 & $139(35)$ \\
$\mathrm{O}(10)$ & $0.2548(11)$ & $0.7580(10)$ & $0.7116(11)$ & 1 & $185(39)$ \\
$\mathrm{O}(11)$ & $0.9637(12)$ & $0.2449(12)$ & $0.1482(11)$ & 1 & $211(38)$ \\
& & & & & \\
\end{tabular}

${ }^{a} U_{\text {eq }}$ is a third of the trace of the orthogonalized $U_{i j}$ tensor.

densed in line via edges are arranged in layers parallel to the $a c$-plane. The resulting short channels in these layers between the clusters are partially occupied by $\mathrm{Tl}$ and $\mathrm{Sn}$ atoms.

Each $\mathrm{Mo}_{6}$ octahedron is coordinated by $\mathrm{O}$ atoms above
Table 3. Powder reflections used in the lattice constant refinement of $\mathrm{Tl}_{0.8} \mathrm{Sn}_{0.6} \mathrm{Mo}_{7} \mathrm{O}_{11}$

\begin{tabular}{lllll}
\hline$h$ & $k$ & $l$ & $l_{\text {rel }}$ & $d_{0} / \mathrm{pm}$ \\
\hline 1 & 1 & 0 & 50 & 671.7 \\
2 & 0 & 0 & 20 & 483.5 \\
0 & 2 & 0 & 30 & 467.9 \\
1 & 1 & 3 & 10 & 322.4 \\
3 & 1 & 0 & 30 & 304.7 \\
1 & 3 & 0 & 100 & 297.0 \\
1 & 3 & 1 & 10 & 290.7 \\
1 & 1 & 3 & 30 & 281.4 \\
3 & 1 & $\frac{1}{1}$ & 10 & 274.5 \\
3 & 2 & $\frac{1}{3}$ & 40 & 270.5 \\
2 & 2 & 10 & 260.5 \\
3 & 1 & 2 & 10 & 237.4 \\
0 & 4 & 0 & 10 & 234.1 \\
1 & 3 & 3 & 10 & 230.9 \\
1 & 2 & 4 & 30 & 226.6 \\
1 & 2 & 4 & 10 & 206.3 \\
3 & 2 & 4 & 10 & 204.2 \\
3 & 1 & 3 & 20 & 203.2 \\
3 & 2 & 3 & 20 & 190.3 \\
1 & 5 & 0 & 30 & 183.9 \\
5 & 2 & 1 & 20 & 183.3 \\
\hline
\end{tabular}

all free edges ( $\mathrm{X}^{\mathrm{i}}$-type positions), i.e. in the manner of an $\mathrm{M}_{6} \mathrm{X}_{12}$-type cluster. ${ }^{2} \mathrm{O}$ atoms from adjacent clusters coordinate all octahedral apices ( $\mathrm{X}^{\mathrm{a}}$-type). The cluster would have the composition " $\mathrm{Mo}_{14} \mathrm{O}_{34}$ " as a free entity. Confining the analysis to only $\mathrm{X}^{\mathrm{i}}$-bonded $\mathrm{O}$ atoms around each $\mathrm{Mo}_{14}$

Table 4. Interatomic distances (in pm) in $\mathrm{TI}_{0.8} \mathrm{Sn}_{0.6} \mathrm{Mo}_{7} \mathrm{O}_{11}$ (standard deviations are given in parentheses). ${ }^{a}$

\begin{tabular}{|c|c|c|c|c|c|c|c|}
\hline $\mathrm{TI}(1)-\mathrm{O}\left(7^{\prime}\right)$ & 262.1(11) & $\mathrm{TI}(2)-\mathrm{Mo}(3)$ & $354.7(3)$ & $M o(1)-M o(2)$ & $281.0(2)$ & $\mathrm{Mo}(4)-\mathrm{O}\left(1^{\prime}\right)$ & $209.2(11)$ \\
\hline $\mathrm{TI}(1)-\mathrm{O}\left(5^{\prime}\right)$ & $266.9(9)$ & $\mathrm{TI}(2)-\mathrm{Mo}\left(5^{\prime}\right)$ & $355.8(3)$ & $\mathrm{Mo}(2)-\mathrm{O}\left(5^{\prime}\right)$ & $201.0(9)$ & $\mathrm{Mo}(4)-\mathrm{Mo}\left(6^{\prime}\right)$ & $276.3(2)$ \\
\hline $\mathrm{TI}(1)-\mathrm{O}\left(11^{\prime \prime \prime \prime}\right)$ & $279.1(12)$ & $\mathrm{Sn}-\mathrm{O}(8)$ & $224.2(11)$ & $\mathrm{Mo}(2)-\mathrm{O}(11)$ & $203.4(12)$ & $\mathrm{Mo}(4)-M o(6)$ & $277.4(2)$ \\
\hline $\mathrm{TI}(1)-\mathrm{O}\left(6^{\prime}\right)$ & $287.3(12)$ & $\mathrm{Sn}-\mathrm{O}\left(9^{\prime \prime \prime}\right)$ & $229.3(10)$ & $\mathrm{Mo}(2)-\mathrm{O}\left(9^{\prime}\right)$ & $206.3(10)$ & $\mathrm{Mo}(5)-\mathrm{O}\left(10^{\prime \prime}\right)$ & $191.7(11)$ \\
\hline $\mathrm{TI}(1)-\mathrm{O}\left(11^{\prime \prime}\right)$ & $288.5(12)$ & $\mathrm{Sn}-\mathrm{O}\left(8^{\prime}\right)$ & $229.9(10)$ & $\mathrm{Mo}(2)-\mathrm{O}\left(4^{\prime}\right)$ & $209.5(12)$ & $\mathrm{Mo}(5)-\mathrm{O}\left(8^{\prime}\right)$ & 197.2(10) \\
\hline $\mathrm{TI}(1)-\mathrm{O}(7)$ & $290.7(11)$ & $\mathrm{Sn}-\mathrm{O}\left(11^{\prime \prime}\right)$ & $287.6(11)$ & $\mathrm{Mo}(2)-\mathrm{O}\left(10^{\prime}\right)$ & $213.4(11)$ & $\mathrm{Mo}(5)-\mathrm{O}\left(9^{\prime}\right)$ & $204.6(11)$ \\
\hline $\mathrm{TI}(1)-\mathrm{O}(6)$ & $291.3(12)$ & $\mathrm{Sn}-\mathrm{O}(6)$ & $293.6(10)$ & $\operatorname{Mo}(2)-M o\left(7^{\prime}\right)$ & $274.3(2)$ & $\mathrm{Mo}(5)-\mathrm{O}(4)$ & $210.1(11)$ \\
\hline $\mathrm{TI}(1)-\mathrm{O}\left(1^{\prime}\right)$ & $294.9(11)$ & $\mathrm{Sn}-\mathrm{O}(3)$ & $295.2(9)$ & $\operatorname{Mo}(2)-M o\left(6^{\prime}\right)$ & $275.7(2)$ & $\mathrm{Mo}(5)-\mathrm{O}(3)$ & $217.6(9)$ \\
\hline $\mathrm{TI}(1)-\mathrm{O}(1)$ & $299.8(11)$ & $\mathrm{Sn}-\mathrm{O}(4)$ & $297.2(11)$ & $\mathrm{Mo}(2)-\mathrm{Mo}(5)$ & $278.1(2)$ & $\mathrm{Mo}(5)-\mathrm{Mo}\left(7^{\prime}\right)$ & $278.7(2)$ \\
\hline $\mathrm{TI}(1)-\mathrm{O}(5)$ & $299.9(9)$ & $\mathrm{Sn}-\mathrm{O}\left(2^{\prime}\right)$ & $305.1(11)$ & $\mathrm{Mo}(2)-\mathrm{Mo}(4)$ & $282.4(2)$ & $\mathrm{Mo}(5)-\mathrm{Mo}(7)$ & $311.6(2)$ \\
\hline $\mathrm{TI}(1)-\mathrm{TI}(2)$ & $284.0(5)$ & $S n-S n^{\prime}$ & $346.3(8)$ & $\mathrm{Mo}(2)-\mathrm{Mo}(7)$ & $304.0(2)$ & $\mathrm{Mo}(6)-\mathrm{O}\left(1^{\prime \prime}\right)$ & $202.2(10)$ \\
\hline $\mathrm{TI}(1)-\mathrm{Sn}$ & $373.7(5)$ & $\mathrm{Sn}-\mathrm{Mo}(5)$ & $340.6(3)$ & $\mathrm{Mo}(3)-\mathrm{O}\left(3^{\prime \prime}\right)$ & $202.9(11)$ & $\mathrm{Mo}(6)-\mathrm{O}(5)$ & $204.8(10)$ \\
\hline $\mathrm{TI}(1)-\mathrm{Mo}(4)$ & $356.4(3)$ & $\mathrm{Sn}-\mathrm{Mo}\left(3^{\prime}\right)$ & $343.7(3)$ & $\mathrm{Mo}(3)-\mathrm{O}\left(6^{\prime}\right)$ & 203.3(12) & $\mathrm{Mo}(6)-\mathrm{O}\left(7^{\prime \prime \prime}\right)$ & $205.5(12)$ \\
\hline $\mathrm{TI}(2)-\mathrm{O}\left(8^{\prime}\right)$ & 269.3(12) & $\mathrm{Sn}-\mathrm{Mo}\left(2^{\prime \prime}\right)$ & $354.1(3)$ & $\mathrm{Mo}(3)-\mathrm{O}\left(7^{\prime \prime}\right)$ & 203.6(11) & $\mathrm{Mo}(6)-\mathrm{O}\left(2^{\prime \prime}\right)$ & 209.3(11) \\
\hline $\mathrm{TI}(2)-\mathrm{O}\left(11^{\prime \prime \prime}\right)$ & $276.4(11)$ & $\mathrm{Mo}(1)-\mathrm{O}\left(1^{\prime \prime}\right)$ & $202.8(12)$ & $\mathrm{Mo}(3)-\mathrm{O}\left(8^{\prime}\right)$ & $205.4(9)$ & $\mathrm{Mo}(6)-\mathrm{Mo}(7)$ & $280.9(2)$ \\
\hline $\mathrm{TI}(2)-\mathrm{O}\left(9^{\prime \prime}\right)$ & $276.5(11)$ & $M o(1)-O\left(6^{\prime}\right)$ & 203.3(11) & $\mathrm{Mo}(3)-\mathrm{O}(2)$ & $208.0(11)$ & $\mathrm{Mo}(7)-\mathrm{O}\left(2^{\prime \prime}\right)$ & $197.2(10)$ \\
\hline $\mathrm{TI}(2)-\mathrm{O}(8)$ & $276.8(10)$ & $M o(1)-O(11)$ & $205.3(12)$ & $\mathrm{Mo}(3)-\mathrm{Mo}\left(7^{\prime}\right)$ & $269.6(2)$ & $\mathrm{Mo}(7)-\mathrm{O}\left(3^{\prime \prime \prime}\right)$ & $197.4(10)$ \\
\hline $\mathrm{TI}(2)-\mathrm{O}\left(6^{\prime}\right)$ & $281.2(10)$ & $\mathrm{Mo}(1)-\mathrm{O}\left(10^{\prime \prime}\right)$ & $210.9(10)$ & $\mathrm{Mo}(3)-\mathrm{Mo}(5)$ & $273.6(2)$ & $\mathrm{Mo}(7)-\mathrm{O}\left(4^{\prime}\right)$ & $210.8(10)$ \\
\hline $\mathrm{TI}(2)-\mathrm{O}\left(3^{\prime}\right)$ & $284.3(9)$ & $M o(1)-M o(5)$ & $275.0(2)$ & $\mathrm{Mo}(3)-\mathrm{Mo}\left(6^{\prime}\right)$ & $280.6(2)$ & $\mathrm{Mo}(7)-\mathrm{O}(4)$ & 211.3(11) \\
\hline $\mathrm{TI}(2)-\mathrm{O}\left(4^{\prime}\right)$ & $287.3(10)$ & $\mathrm{Mo}(1)-\mathrm{Mo}\left(6^{\prime}\right)$ & $275.0(2)$ & $\mathrm{Mo}(3)-\mathrm{Mo}\left(4^{\prime}\right)$ & $285.6(2)$ & $\mathrm{Mo}(7)-\mathrm{O}\left(9^{\prime}\right)$ & $212.5(11)$ \\
\hline $\mathrm{TI}(2)-\mathrm{O}(2)$ & $292.6(11)$ & $\mathrm{Mo}(1)-\mathrm{Mo}\left(4^{\prime}\right)$ & $276.2(2)$ & $\mathrm{Mo}(4)-\mathrm{O}\left(7^{\prime \prime \prime}\right)$ & $205.0(12)$ & $\mathrm{Mo}(7)-\mathrm{Mo}\left(7^{\prime}\right)$ & $299.1(3)$ \\
\hline $\mathrm{TI}(2)-\mathrm{O}\left(7^{\prime}\right)$ & $295.5(12)$ & $\mathrm{Mo}(1)-\mathrm{Mo}(6)$ & $276.9(2)$ & $\mathrm{Mo}(4)-\mathrm{O}\left(5^{\prime}\right)$ & $205.9(11)$ & & \\
\hline $\mathrm{Tl}(2)-\mathrm{O}\left(10^{\prime}\right)$ & $300.4(11)$ & $\mathrm{Mo}(1)-\mathrm{Mo}(4)$ & $277.0(2)$ & $\mathrm{Mo}(4)-\mathrm{O}(6)$ & $206.0(10)$ & & \\
\hline $\mathrm{Tl}(2)-\mathrm{O}\left(5^{\prime}\right)$ & $304.9(12)$ & $\mathrm{Mo}(1)-\mathrm{Mo}(3)$ & $280.9(2)$ & $\mathrm{Mo}(4)-\mathrm{O}(11)$ & $207.2(11)$ & & \\
\hline
\end{tabular}

a Symmetry coding: $x, y, z:() ;-x,-y,-z:\left({ }^{\prime}\right) ; 1 / 2-x, 1 / 2+y,-z:\left({ }^{\prime \prime}\right) ;-1 / 2+x,-1 / 2-y, z:\left({ }^{\prime \prime \prime}\right)$. 

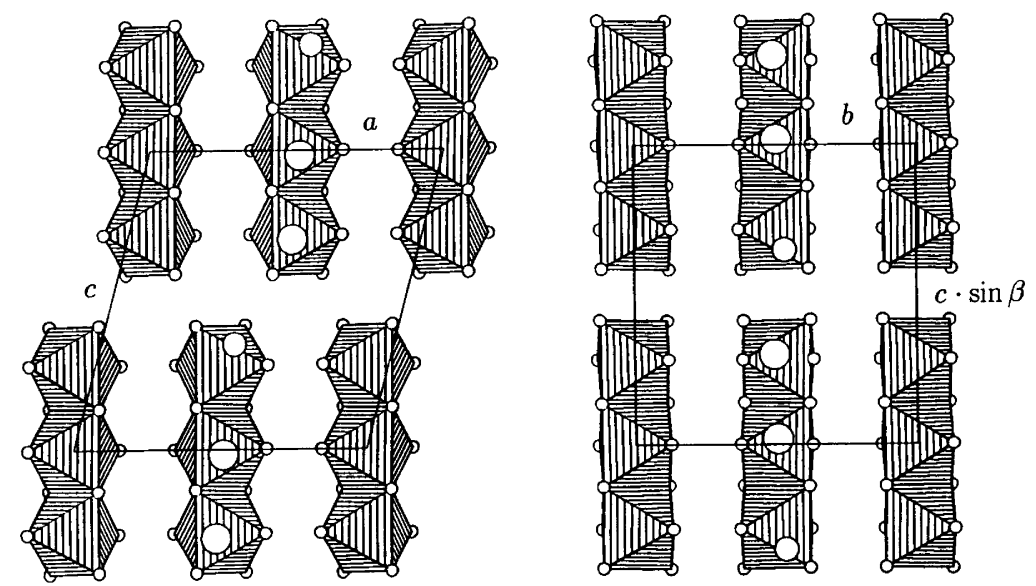

Fig. 2. Polyhedral representation ${ }^{38}$ of the metal atom substructure of $\mathrm{Tl}_{0.8} \mathrm{Sn}_{0.6} \mathrm{Mo}_{7} \mathrm{O}_{11}$ along [010] (left) and [100] (right); Mo atoms are shown as small circles, $\mathrm{Tl}$ atoms as large circles and $\mathrm{Sn}$ atoms as medium-sized circles, with both of the possible positions of the structural fragment TI-TI-Sn (left $\uparrow$, right $\downarrow$ ), see text. The cluster centres lie at $0,1 / 2,0$ and $1 / 2,0,0$. For the labelling of the Mo, TI and $\mathrm{Sn}$ atoms, see Figs. 3 and 4 , respectively.

core, the connectivity scheme is represented by the formula $\mathrm{Mo}_{14} \mathrm{O}_{10}^{\mathrm{i}} \mathrm{O}_{4 / 2}^{\mathrm{i}-\mathrm{i}} \mathrm{O}_{20 / 2}^{\mathrm{i} i \mathrm{a}}\left(=\mathrm{Mo}_{14} \mathrm{O}_{22}=2 \times \mathrm{Mo}_{7} \mathrm{O}_{11}\right)$. Four $\mathrm{O}$ atoms of the inner sphere belong to just one cluster. A view of the new cluster anion is given in Fig. 3.

The range of Mo-O distances is $191-218 \mathrm{pm}$ and is slightly wider than in the compound $\mathrm{PbMo}_{5} \mathrm{O}_{8} .{ }^{11}$ The average $\mathrm{Mo}-\mathrm{O}$ distance is $206 \mathrm{pm}$ and corresponds to that in $\mathrm{In}_{11} \mathrm{Mo}_{40} \mathrm{O}_{62}(207 \mathrm{pm})$ or $\mathrm{PbMo}_{5} \mathrm{O}_{8}(206 \mathrm{pm})$.

A detailed analysis of the interatomic distances has been performed with the help of bond-length-bond-strength calculations. ${ }^{12,24}$ As can be seen from Table 5 there is an obvious difference in the bond order sums between two groups of Mo atoms. Mo atoms near the centre of the cluster $[\mathrm{Mo}(1)$ and $\mathrm{Mo}(6)]$ have bond order sums of about 2.4 , in contrast to all others, which have bond order sums between 2.9 and 3.2 owing to the greater number of coordinated $\mathrm{O}$ atoms. This effect is very similar to the findings in $\mathrm{PbMo}_{5} \mathrm{O}_{8}{ }^{11}$

Within the cluster the Mo-Mo distances lie between 270 and $286 \mathrm{pm}$. The average value is $278 \mathrm{pm}$ and shows a small increase of $3 \mathrm{pm}$ with respect to the value in $\mathrm{PbMo}_{5} \mathrm{O}_{8}$, approaching the value in $\operatorname{In}_{11} \mathrm{Mo}_{40} \mathrm{O}_{62}(279 \mathrm{pm})$. Therefore, an increase in cluster length manifests itself in a small but still significant lengthening of the intra-cluster distances.

Compared to the Mo-Mo distances in $\mathrm{In}_{11} \mathrm{Mo}_{40} \mathrm{O}_{62}$ the Mo-Mo distances in $\mathrm{Tl}_{0.8} \mathrm{Sn}_{0.6} \mathrm{Mo}_{7} \mathrm{O}_{11}$ are surprisingly similar. $^{25}$ The Mo-Mo distances of the shared edges $[\operatorname{Mo}(1)-\operatorname{Mo}(6)$ and $\operatorname{Mo}(5)-\operatorname{Mo}(7)]$ are $278 \pm 1 \mathrm{pm}$, and the Mo-Mo distances between the apical Mo atoms $[\mathrm{Mo}(3)-\mathrm{Mo}(4)-\mathrm{Mo}(2)]$ are $284 \pm 2 \mathrm{pm}$. Short $(270 \mathrm{pm})$ and long distances $(281 \mathrm{pm})$ can only be found at $\operatorname{Mo}(7)$, which simultaneously has the shortest contacts to the next oligomeric cluster.

These inter-cluster distances are $299 \mathrm{pm}(1 \times), 304 \mathrm{pm}$ $(2 \times)$ and $312 \mathrm{pm}(2 \times)$. They are longer than the compara- ble distances in $\mathrm{PbMo}_{5} \mathrm{O}_{8}$ and much bigger than the average intra-cluster distance. For that reason the clusters prove to be (electronically) more isolated than in $\mathrm{PbMo}_{5} \mathrm{O}_{8}$. The Mo-Mo bond order sum for the five shortest inter-cluster distances reaches a value of 0.9 , i.e. there are 0.9 electrons used in inter-cluster metal-metal bonding per formula unit of $\mathrm{Tl}_{0.8} \mathrm{Sn}_{0.6} \mathrm{Mo}_{7} \mathrm{O}_{11}$.

Concerning the coordination of the $\mathrm{Tl}$ atoms, a cube-like arrangement of $\mathrm{O}$ atoms is found for both independent atoms. The $\mathrm{Tl}$ atoms are slightly shifted from the centres of gravity of the coordination polyhedra towards the inversion centre. Bond-length-bond-strength calculations (Table 5) show them to be divalent. This finding is in agreement with the short $\mathrm{Tl}(1)-\mathrm{Tl}(2)$ distance of $284 \mathrm{pm}$, representing a Tl-Tl single bond. ${ }^{26}$

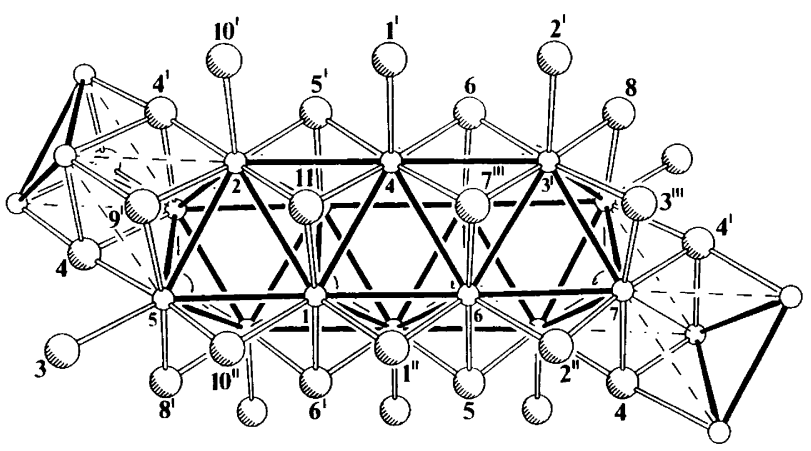

Fig. 3. Perspective view ${ }^{17}$ of the Mo-O cluster in $\mathrm{TI}_{0.8} \mathrm{Sn}_{0.6} \mathrm{MO}_{7} \mathrm{O}_{11}$ together with fragments of adjacent clusters. Mo atoms are drawn as small circles and $\mathrm{O}$ atoms as large circles. The atom labelling refers to Table 5; the inversion centre of the structure and the centre of the cluster coincide. The shortest inter-cluster bond is emphasized as a full, thin line, the others as broken lines. One $O\left(9^{\prime}\right)$ atom has been omitted on the right hand side. 
Table 5. Bond-order sums $[4,12,21,22]$ of the metal atoms with respect to oxygen in $\mathrm{Tl}_{0.8} \mathrm{Sn}_{0.6} \mathrm{Mo}_{7} \mathrm{O}_{11}$.

\begin{tabular}{ll}
\hline Atom & Valence \\
\hline $\mathrm{TI}(1)$ & \\
$\mathrm{TI}(2)$ & 1.7 \\
$\mathrm{Sn}$ & 1.8 \\
$\mathrm{Mo}(1)$ & 2.2 \\
$\mathrm{Mo}(2)$ & 2.4 \\
$\mathrm{Mo}(3)$ & 2.9 \\
$\mathrm{Mo}(4)$ & 3.0 \\
$\mathrm{Mo}(5)$ & 2.9 \\
$\mathrm{Mo}(6)$ & 3.2 \\
$\mathrm{Mo}(7)$ & 2.4 \\
\hline
\end{tabular}

a Parameters: TI with $R_{0}=2.100 \AA, N=6.0$; Sn with

$R_{0}=1.860 \AA, N=4.5 ;$ Mo with $R_{0}=1.882 \AA, N=6.0$.

As in the case of divalent $\mathrm{Al},{ }^{27} \mathrm{Ga}^{28-32}$ or In, ${ }^{7.33-35}$ the remaining valence electron of $\mathrm{Tl}^{2+}$ is used for homonuclear bonding. $\mathrm{A} \mathrm{Tl}_{2}{ }^{4+}$ species which is isoelectronic and isostructural with $\mathrm{Hg}_{2}{ }^{2+}$ was hitherto unknown.

Of course, the local statistical disorder of the cation allows an alternative occupation of the Tl position to yield a Tl-Tl distance of $320 \mathrm{pm}$. Such a model is very unlikely owing to the loss of spin-pairing energy, and can be ruled out from magnetic measurements which will be described for the series of oligomeric cluster oxomolybdates in a forthcoming paper. Last, but not least, the convergence of the $\mathrm{Tl}(1)$ and $\mathrm{Tl}(2)$ site occupation factors to identical values is in agreement with the assumption of $\mathrm{Tl}_{2}{ }^{4+}$ ions. The statistical disorder of the "Tl-Tl-Sn" unit (in contrast to a model of inversion twins) is easily rationalized in terms of an alternative 40 and $60 \%$ occupation of the voids between the molybdate clusters by $\mathrm{Tl}_{2}{ }^{4+}$ and $\mathrm{Sn}^{2+}$ ions, respectively.

Thus, each channel is occupied by only one of the two ions, $\mathrm{Tl}_{2}^{4+}$ or $\mathrm{Sn}^{2+}$, each in two possible positions, which nicely explains why the refined position of, e.g., $\mathrm{Sn}^{2+}$ does not exhibit a split pattern depending on whether the adjacent channel position is empty or occupied by a $\mathrm{Sn}^{2+}$ or $\mathrm{Tl}_{2}{ }^{4+}$ ion, respectively. The partial occupation of the available voids again reflects the rigidity of such cluster frameworks, which is well-documented in other systems: $\mathrm{In}_{2} \mathrm{Mo}_{15} \mathrm{Se}_{19}$ can be modified by "soft chemistry" to yield the empty cluster framework in the compound $\mathrm{Mo}_{15} \mathrm{Se}_{19} \cdot{ }^{36}$

The coordination of the $\mathrm{Sn}$ atom is characterized by three short Sn-O bonds in the range 224-230 pm, and no simple coordination polyhedron exists. The bond order sum shows the $\mathrm{Sn}$ atom to be divalent, as expected. The shortest $\mathrm{Sn}-\mathrm{Sn}$ distance in the averaged structure is found to be $346 \mathrm{pm}$, but according to the above discussion one would in any case expect the adjacent position to be empty. For that reason the $\mathrm{Sn}$ atom (like the $\mathrm{Pb}$ atom in $\mathrm{PbMo}_{5} \mathrm{O}_{8}$ ) simply acts as a two-electron donor for the oxomolybdate cluster.

Fig. 4 presents a perspective view of the coordinations of the $\mathrm{Sn}^{2+}$ and $\mathrm{Tl}_{2}{ }^{4+}$ ions by oxygen atoms. It is remarkable that the cationic disorder is not reflected in the "thermal" ellipsoids for the $\mathrm{O}$ atoms. Obviously the Mo-O skeleton is largely a rigid unit, very much as in the oxoniobates, where the "hierarchy of bond strengths" has been discussed in more detail. ${ }^{37}$

To summarize what has been said about the valence states of the cations and inter-cluster bonding in $\mathrm{Tl}_{0.8} \mathrm{Sn}_{0.6} \mathrm{Mo}_{7} \mathrm{O}_{11}$, one can make up an electron balance to count the number of valence electrons which are left for intra-cluster bonding. According to eqn. (5) one finds 21.9

$\underbrace{7 \times 6}_{\mathrm{Mo}}+\underbrace{0.4 \times 4}_{\mathrm{Tl}}+\underbrace{0.6 \times 2}_{\mathrm{Sn}}-\underbrace{11 \times 2}_{\mathrm{O}}-\underbrace{0.9}_{\text {inter }}=21.9$

electrons per $\mathrm{Mo}_{7} \mathrm{O}_{11}$ unit, which leads to 3.13 electrons per Mo atom, in excellent agreement with the predicted value of 3.1(2). ${ }^{5}$ Obviously the intercluster bonding is necessary to reduce the number of Mo-centred valence electrons which otherwise would enter antibonding cluster states.

Acknowledgements. We thank Dr. K. Peters for the X-ray data collection. Mrs. O. Buresch for the chemical analysis, Mrs. E. Winckler for the SEM photograph and the Fonds der Chemischen Industrie for support.
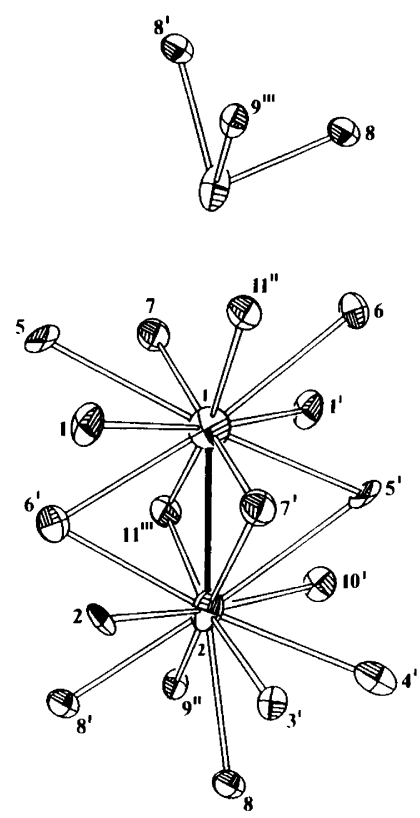

Fig. 4. Perspective view ${ }^{17}$ of the $\mathrm{Sn}$ (top) and $\mathrm{TI}$ (middle and bottom) coordination spheres in $\mathrm{TI}_{0.8} \mathrm{Sn}_{0.6} \mathrm{Mo}_{7} \mathrm{O}_{11}$ by $\mathrm{O}$ atoms up to 285 and $305 \mathrm{pm}$, respectively. The labelling of the $\mathrm{TI}$ atoms (small numbers) and the $\mathrm{O}$ atoms (bigger numbers) refers to Table 5. The ellipsoids enclose $70 \%$ of the electrons' spatial probability. the TI-TI single bond is emphasized with a thick line. 


\section{References}

1. Torardi, C. C. and McCarley, R. E. J. Am. Chem. Soc. 101 (1979) 3963.

2. Schäfer, H. and Schnering, H. G. Angew. Chem. 76 (1964) 833.

3. Hughbanks, T. and Hoffmann, R. J. Am. Chem. Soc. 105 (1983) 3528.

4. McCarley, R. E., Lii, K.-H., Edwards, P. A. and Brough, L. F. J. Solid State Chem. 57 (1985) 17

5. Simon, A. Angew. Chem. 100 (1988) 163; Angew. Chem., Int. Ed. Engl. 27 (1988) 159.

6. Simon, A. Angew. Chem. 93 (1981) 23; Angew. Chem., Int. Ed. Engl. 20 (1981) 1.

7. Mattausch, H., Simon, A. and Peters, E.-M. Inorg. Chem. 25 (1986) 3428.

8. Lii, K. H., Wang, C. C. and Wang, S. L. J. Solid State Chem. 77 (1988) 407.

9. Hibble, S. J., Cheetham, A. K., Bogle, A. R. L., Wakerley, H. R. and Cox, D. E. J. Am. Chem. Soc. 110 (1988) 3295.

10. Dronskowski, R. and Simon, A. Angew. Chem. 101 (1989) 775; Angew. Chem., Int. Ed. Engl. 28 (1989) 758.

11. Dronskowski, R., Simon, A., and Mertin, W. Z. Anorg. Allg. Chem. Submitted.

12. Sheldrick, G. M. SHELXS-86, Program for Crystal Structure Determination, Universität Göttingen, Göttingen, FRG 1986.

13. According to Pauling's single valence radii [Pauling, L. The Nature of the Chemical Bond, 3rd. ed., Cornell University Press, Ithaca NY, 1960] the Tl atom (115 pm) is nearly $19 \mathrm{pm}$ larger than the $\mathrm{Sn}$ atom $(96 \mathrm{pm})$.

14. Eitel, M. and Bärnighausen, H. SFLS, Version zur Verfeinerung von Datensätzen verzwillingter oder verdrillingter Kristalle nach der Methode der kleinsten Quadrate, Universität Karlsruhe, Karlsruhe, FRG 1986.

15. Walker, N. and Stuart, D. Acta Crystallogr., Sect. A39 (1983) 158

16. Sheldrick, G. M., SHELX-76, Program for Crystal Structure Determination, Cambridge University, Cambridge, UK 1976.

17. SHELXTL-Plus, Rel. 3.4, Nicolet Instrument Corporation 1988.

18. $R$ value definitions:

$R=\Sigma|| F_{\mathrm{o}}|-| F_{\mathrm{c}}|| / \Sigma\left|F_{\mathrm{o}}\right|$,

$R_{\mathrm{w}}=\Sigma\left[|| F_{\mathrm{o}}|-| F_{\mathrm{c}}|| \sigma^{-2}\left(F_{\mathrm{o}}\right)\right] / \Sigma\left[\left|F_{\mathrm{o}}\right| \sigma^{-2}\left(F_{\mathrm{o}}\right)\right]$.

19. Only for the $\operatorname{Tl}(1)$ atom was a strong correlation between site parameters and $U_{33}$ found because of the neighbouring symmetry equivalent position $(41 \mathrm{pm})$. To perform a meaningful anisotropic refinement, site parameters and displacement parameters were allowed to be refined alternatively until a constant $R$ value resulted. Therefore the standard deviations for the $\mathrm{Tl}(1)$ atom are slightly decreased. For the calculation of the interatomic distances of $\operatorname{Tl}(1)$ the same standard deviations as for $\mathrm{Tl}(2)$, namely 0.0003 in $x, y$ and $z$, were used.

20. Simon, A. J. Appl. Crystallogr. 3 (1970) 11.

21. Tebbe, K.-F. Thesis, Universität Münster, Münster, FRG 1970.
22. Busing, W. R., Masten, K. D. and Levy, J. A. ORFFE-3, ORNL-TM-306, Oak Ridge National Laboratory, Oak Ridge, TN 1971.

23. A list of the observed and calculated structure factors and anisotropic thermal parameters may be obtained from the Fachinformationszentrum Karlsruhe, D-7514 Eggenstein-Leopoldshafen 2 , on quoting the depository number CSD-53673, the authors' names and the journal citation.

24. For the TI-O and Sn-O bonds we use the relationship and parameters given by Brown [Brown, I. D. In: O'Keefe, M. and Navrotsky, A., Eds., Structure and Bonding in Crystals, Academic Press, New York 1981, Vol. II], eqn. (1), for the

$s=\left(R / R_{0}\right)^{-N}$

Mo-O bonds the formula of Brown and Wu [Brown, I. D. and Wu, K. K. Acta Crystallogr., Sect. B 32 (1976) 1957], eqn. (2),

$s_{\mathrm{Mo}-\mathrm{O}}=[d(\mathrm{Mo}-\mathrm{O}) / 1.882 \AA]^{-6.11}$

which McCarley et al. [Ref. 4] stated to be well-suited for metal-rich Mo oxides. Mo-Mo bond orders can be obtained with the help of Pauling's formula [Ref. 4], eqn. (3).

$s_{\mathrm{Mo-Mo}}=10^{[2.614 \AA ⿻ d(\mathrm{Mo}-\mathrm{Mo}) / 0.6 \AA]}$.

25. For $\operatorname{In}_{11} \mathrm{Mo}_{41} \mathrm{O}_{62}$ the Mo-Mo distances of the shared edges show a short-long-short pattern while proceeding from the centre of the cluster to its end. All the other Mo-Mo bonds decrease continously as they approach the cluster's end.

26. According to Pauling's covalent radius for the Tl atom (143.7 pm) [Ref. 13], one expects a Tl-Tl single bond distance of about $287 \mathrm{pm}$.

27. Nesper, R. and Curda, J. Z. Naturforsch., Teil B42 (1987) 557.

28. Brown, K. L. and Hall, D. J. Chem. Soc., Dalton Trans., $1973,1843$.

29. Gerlach, G., Hönle, W. and Simon, A. Z. Anorg. Allg. Chem. $486(1982) 7$.

30. Hönle, W., Gerlach, G., Weppner, W. and Simon, A. J. Solid State Chem. 61 (1986) 171.

31. Hönle, W. and Simon, A. Z. Naturforsch., Teil 3 (1986) 1391.

32. Paashaus, S. and Kniep, R. Angew. Chem. 98 (1986) 725; Angew. Chem., Int. Ed. Engl. 25 (1986) 752.

33. Hogg, J. H. C. and Duffin, W. J. Acta Crystallogr. 23 (1967) 111.

34. Hogg, J. H. C. Acta Crystallogr., Sect. B 27 (1971) 1630.

35. Waterworth, L. and Worrall, I. J. Inorg. Nucl. Chem. Lett. 8 (1972) 123

36. Tarascon, J. M., Hull, G. W. and Waszczak, J. V. Mater. Res. Bull. 20 (1985) 935.

37. Köhler, J. and Simon, A. Z. Anorg. Allg. Chem. 553 (1987) 106.

38. Fischer, R. X. J. Appl. Crystallogr. 18 (1985) 258.

Received January 2, 1990. 